\title{
Bank Lending Channel of Monetary Policy Transmission: New Evidence From Indonesia
}

\author{
Ahmad Albar Tanjung \\ Management, SekolahTinggi Ilmu Manajemen Sukma, Medan, Indonesia
}

\{alb4rt4njung@gmail.com\}

\begin{abstract}
Monetary policy can affect the economy through a variety of channels. Using quarterly secondary data from 2010: 1 to 2020: 2. This paper examines the bank lending channel to provide new evidence and explain the transmission mechanism in Indonesia. The estimation method used is a Vector Error Correction Model (VECM). The result of the VECM analysis shows that the Monetary Policy transmission mechanism through the bank lending channel still has a weak influence on the output. Therefore, from the demand side, it is necessary to seek new market shares for export purposes, also, to maintain existing ones to restore domestic corporate credit demand, and from the supply side, banks must provide easy access for MSMEs to obtain loans while still prioritizing the principle of prudence.
\end{abstract}

Keywords: Monetary Policy, Bank Lending, Output, VECM

\section{Introduction}

Monetary policy has always been an important issue for researchers in the fields of economics, government, political observers, and even ordinary people. Monetary policy is any business undertaken by the monetary authority by using various instruments to achieve the final target set by the monetary authority, namely low and stable inflation along achieve sustainable economic growth (Tanjung, et al., 2017; Anwar, S., and Phi, 2018; Tanjung, et al., 2019). The multiple-channel mechanism used by the monetary authority to influence the economy is called the monetary policy transmission mechanism. The monetary transmission mechanisms consist of: the exchange rate, the asset price, the interest rate, the corporate balance sheet, the expectations, and the credit channels. The most popular channel that appears in current monetary policy research in developed countries and emerging market countries such as Indonesia is the interest rate channel, this is because interest rates are used by most central banks as part of monetary policy instruments (Sun, Gan, \& Hu, 2010). On the other hand, the credit channel has begun to attract the attention of research and monetary policymakers in recent decades. Credit channels can be divided into two categories, they are the bank lending channel (narrow credit channel) and the balance sheet channel (broad credit channel).

In theory, if the transmission of monetary policy through the bank lending channel goes well, it will have an impact on investment growth and development, this growing and developing investment will have a huge multiplier effect on the growth of other sectors which 
will ultimately have an impact on economic growth(Mishkin, 2004). In principle, bank credit is very important in financing the economy and as a driving force for economic growth (Utari, Arimurti, \&Kurniati, 2012). Several previous studies support the theory above which states that monetary policy using bank lending channels has a strong and broad influence on the real sector and prices (Bernanke \& Blinder, 1988; Bernanke \& Blinder, 1992; Kashyap\& Stein, 2000).

In Indonesia, the exchange rate and interest rate channel show a clear and strong role in the mechanism of monetary policy while other channels have not shown a clear and strong role in the transmission mechanism of monetary policy, however, the interest to continue to study it is higher (Goeltom, M., 2005). After the 1997 crisis, Indonesia experienced a decline in bank lending as a result of the economic recovery. on the other hand, post-crisis inflation, exchange rates, and interest rates have shown better conditions, however, credit provided by banks has not been able to restore economic growth in the pre-crisis situation (Basith, 2007). However, there are still some important questions that will remain in the literature at this time. The purpose of this paper is to examine the bank lending channel to provide new evidence and to improve the current literature on bank lending channels in the transmission of Indonesian monetary policy.

Bank Lending Channels are very important in the banking system, this is because the Bank Lending channel can solve the problem of asymmetric information in the credit market because certain borrowers will not have access to the credit market unless they borrow from the bank. This Bank Lending Channel will do well if certain borrowers will not have access to the credit market unless they borrow from a bank. According to Miskin (2004), the mechanism of monetary policy transmission through the Bank Lending Channel is: monetary policy expansion through Money Supply (M1) will cause an increase in bank deposits, further increasing the number of bank loans, increasing the number of bank loans will increase investment which in turn will increase the output. The bank lending channel shows a certain role in the bank, namely paying attention to the borrower's ability to make repayments, unlike the channel balance sheet.

The results of the study (Aban, 2013) state that the growth of small bank loans is very sensitive to changes in monetary policy through the bank lending channel, this can be seen in the increase in policy interest rates which affect decreasing loan supply to small banks. Research results (Abuka, Alinda, Minoiu, Peydró, \&Presbitero, 2019) state that monetary policy through bank lending in developing countries is still weak, this is due to banking policies to reduce credit offers and refuse new credit applications. Research results (Mahathanaseth\&Tauer, 2019) state that bank lending channels at small banks are better than large banks, bank lending channels are an important channel for monetary policy transmission in Thailand.

In Indonesia, research related to monetary policy through bank credit channels has been carried out, such as: (Goeltom, M., 2005) stated that monetary shocks can affect bank lending channels with a relatively long lag time and bank lending channels are more sensitive to shocks. monetary for domestic private banks, banks with low capital, and for individual loans. Research results (Utari et al., 2012; Khaliq, 2013) state that real sector development through bank loan channels is achieved optimally. The results of research by Yarasevika, Tongato, \&Muthia (2015) state that In the short term, real while Bank Loans are negatively affected by interest rates on bank loans based on the results of the VECM analysis so that Banks need to reduce loan interest rates to increase investment so that people can borrow easily from banks with low-interest rates. The findings (Mentari N, Hayati, \& A G, 2018) also state that 
monetary policy transmission using the inflation expectation channel is better than the interest rate and credit channel in achieving the inflation target.

\section{Methods}

All data of this research are quarterly frequencies and covered periods 2010:1 until 2020:2 to examine and give new evidence the existence of the bank lending channel in the transmission of Indonesia's monetary policy that obtained from source Bank of Indonesia. This research period was chosen as a continuation of previous studies related to the monetary policy transmission mechanism in Indonesia. The variables used in this study are the variables Money Supply (M1), Bank deposit (DEP), bank Loan (LON), Investment (INV), and Output (PDB). Some of the steps taken before estimating the VECM model are the Stationarity Test, Optimum Lag Test, and Cointegration Test(Verbeek, 2004; Firdaus, 2020).

Data analysis using the VAR model (Vector Autoregression) or VECM (Vector Error Correction Model). The general VAR equation model can be written as follows:

$$
\begin{aligned}
\operatorname{LOG}(\mathrm{PDB})_{\mathrm{t}}= & \left.\left.\alpha_{0}+\sum_{\mathrm{i}=1}^{\mathrm{j}} \alpha_{\mathrm{i}} \operatorname{LOG}(\mathrm{M} 1)\right)\right)_{\mathrm{t}-\mathrm{i}}+\sum_{\mathrm{i}=1}^{\mathrm{j}} \alpha_{\mathrm{i}} \operatorname{LOG}(\mathrm{DEP})_{\mathrm{t}-\mathrm{i}}+\sum_{\mathrm{i}=1}^{\mathrm{j}} \alpha_{\mathrm{i}} \operatorname{LOG}(\mathrm{LON})_{\mathrm{t}-\mathrm{i}}+ \\
& \sum_{\mathrm{i}=1}^{\mathrm{j}} \alpha_{\mathrm{i}} \operatorname{LOG}(\operatorname{INV})_{\mathrm{t}-\mathrm{i}}+\varepsilon_{\mathrm{t}}
\end{aligned}
$$

\section{Results and Discussion}

Before regressing the times series data, first of all, what must be done is to look at whether or not the data used for this study are stationary using the Unit Roots Test. The unit root test was carried out for each variable in the study, namely output (PDB), Monetary Aggregate M1 (JUB), deposit (DEP), Loan (LON), and Investment (INV). The unit root test is done by the Augmented Dickey-Fuller Test approach (ADF).

Table 1. ADF Unit Root Test

\begin{tabular}{cccccc}
\hline No & Variable & ADF values & critical values*) & Prob. & Stationary at \\
\hline 1 & M1 & -15.80142 & -3.605593 & $0,0000<0,01$ & 1 st Difference \\
2 & DEP & -5.006167 & -3.639407 & $0,0003<0,01$ & 1 st Difference \\
3 & LON & -5.787663 & -3.605593 & $0,0000<0,01$ & 1 st Difference \\
4 & INV & -5.832073 & -3.6000987 & $0,0000<0,01$ & level \\
5 & PDB & -8.475939 & -3.610453 & $0,0000<0,01$ & 1 st Difference \\
\hline
\end{tabular}

We have conducted the stationarity test. The results show that the investment variable (INV) is stationary at the level, while the other variables are stationary at the first difference. The next step is determining the optimal lag. The optimal lag test in this study uses the minimum AIC criteria. The optimal lag test results can be seen in the table below.

Table 2. Results of Determination of Optimal Lag

\begin{tabular}{ccccccc}
\hline Lag & LogL & LR & FPE & \multicolumn{1}{c}{ AIC } & SC & HQ \\
\hline 0 & 163.9282 & NA & $1.99 \mathrm{e}-10$ & -8.150162 & -7.936885 & -8.073640 \\
1 & 319.9527 & 264.0415 & $2.43 \mathrm{e}-13$ & -14.86937 & $-13.58971^{*}$ & -14.41024 \\
2 & 358.3333 & 55.11065 & $1.31 \mathrm{e}-13$ & -15.55556 & -13.20951 & -14.71381 \\
3 & 395.2123 & $43.49829 *$ & $8.49 \mathrm{e}-14 *$ & $-16.16473^{*}$ & -12.75230 & $-14.94038^{*}$ \\
\hline
\end{tabular}


Based on the test results above and based on the AIC criteria with a value of -16.16473 being at lag 3, lag 3 was chosen as the optimum lag. The next step is to test the stability of the VAR system at this optimal lag. Estimated VAR is stable if all its roots have a modulus less than one and are located in its unit circle. The stability test results of the VAR system show the Modulus range, namely: 0.314744-0.999315. Next, cointegration testing is carried out. Cointegration refers to several variables integrated to the same degree. In this study, the cointegration test was carried out at degree I (1). The results of the cointegration test can be seen in the table below:

Table 3. Cointegration Test Results

\begin{tabular}{cccc}
\hline \multicolumn{4}{c}{ UnrestricedCointegration Rank Test (Trace) } \\
\hline $\mathbf{H}_{\mathbf{0}}$ & Trace Statistic & $\mathbf{0 . 0 5}$ Critical Value & Prob. ${ }^{* *}$ \\
\hline $\mathrm{r}=0^{*}$ & 103.7338 & 69.81889 & 0.0000 \\
$\mathrm{r}=1 *$ & 63.88977 & 47.85613 & 0.0008 \\
\hline \multicolumn{4}{c}{ Unrestricted Cointegration Rank Test (Maximum Eigenvalue) } \\
\hline $\mathbf{H}_{\mathbf{0}}$ & Max-Eigen Statistic & $\mathbf{0 . 0 5}$ Critical value & Prob. ${ }^{* *}$ \\
\hline $\mathrm{r}=0^{*}$ & 46.89150 & 33.87687 & 0.0008 \\
$\mathrm{r}=1 *$ & 37.15765 & 27.58434 & 0.0022 \\
\hline
\end{tabular}

Based on the table above, it can be seen that the Trace Statistic value is greater than the critical value, namely: $103.7338>69.81889$ and the maximum Eigen statistic value is greater than the critical value, namely: $46.89150>33.87687$. Thus it is evident that there is cointegration in the model so that the Vector Error Correction Model (VECM) modeling can be continued because it has met the second requirement, namely the occurrence of cointegration (long-term balance). The VECM estimation results for bank lending channels can be seen below:

Table 4. Short Term VECM Estimation Results

\begin{tabular}{lrr}
\multicolumn{1}{c}{ Variable } & Coefisien & T-Statistic \\
\hline CointEq1 & -0.218071 & -1.15713 \\
$\mathrm{D}(\log (\mathrm{PDB}(-1)))$ & 0.405268 & 1.27112 \\
$\mathrm{D}(\log (\mathrm{PDB}(-2)))$ & -0.501136 & -1.60066 \\
$\mathrm{D}(\log (\mathrm{PDB}(-3)))$ & 0.032710 & 0.09738 \\
$\mathrm{D}(\log (\mathrm{M} 1(-1)))$ & -0.259237 & -1.02030 \\
$\mathrm{D}(\log (\mathrm{M} 1(-2)))$ & -0.297786 & -1.30254 \\
$\mathrm{D}(\log (\mathrm{M} 1(-3)))$ & -0.082598 & -0.36732 \\
$\mathrm{D}(\log (\mathrm{DEP}(-1)))$ & 0.450211 & 0.92996 \\
$\mathrm{D}(\log (\mathrm{DEP}(-2)))$ & 0.602701 & 1.40117 \\
$\mathrm{D}(\log (\mathrm{DEP}(-3)))$ & 0.344232 & 0.69572 \\
$\mathrm{D}(\log (\operatorname{LON}(-1)))$ & 0.044810 & 0.59489 \\
$\mathrm{D}(\log (\operatorname{LON}(-2)))$ & -0.021485 & -0.28606 \\
$\mathrm{D}(\log (\operatorname{LON}(-3)))$ & 0.000774 & 0.00760 \\
$\mathrm{D}(\log (\mathrm{INV}(-1)))$ & 0.012558 & 1.24498 \\
$\mathrm{D}(\log (\mathrm{INV}(-2)))$ & 0.003521 & 0.39351 \\
$\mathrm{D}(\log (\mathrm{INV}(-3)))$ & 0.002666 & 0.40329 \\
$\mathrm{C}$ & -0.010718 & -0.51045 \\
\hline
\end{tabular}

Based on the table above, it can be seen that in the short term there are variables that have a significant effect on output. Furthermore, to see the long-term effect, it can be seen in the results below. 
Table 5. Long Term VECM Result

\begin{tabular}{lrr}
\hline \multicolumn{1}{c}{ Variable } & Coefisien & T-statistic \\
\hline $\log (\mathrm{M} 1(-1))$ & -1.295013 & -7.56033 \\
$\log (\mathrm{DEP}(-1))$ & 1.073639 & 4.22925 \\
$\log (\operatorname{LON}(-1))$ & -0.190929 & -3.47878 \\
$\log (\mathrm{INV}(-1))$ & 0.073694 & 4.17292 \\
$\mathrm{C}$ & -11.04959 & \\
\hline
\end{tabular}

The table above shows that in the long run, all variables are significant to output. Money Supply has a significant negative effect on output, Banking Deposits have a positive and significant effect on output, Banking Credit has a negative and significant effect on output and Investment has a positive and significant effect on output, it means that if there is an increase of one percent in investment it will increase output to 0.073694 percent. However, because our focus is on seeing how the transmission of monetary policy through bank lending channels, we continue to use Impulse Response and Variance Decomposition Analysis.

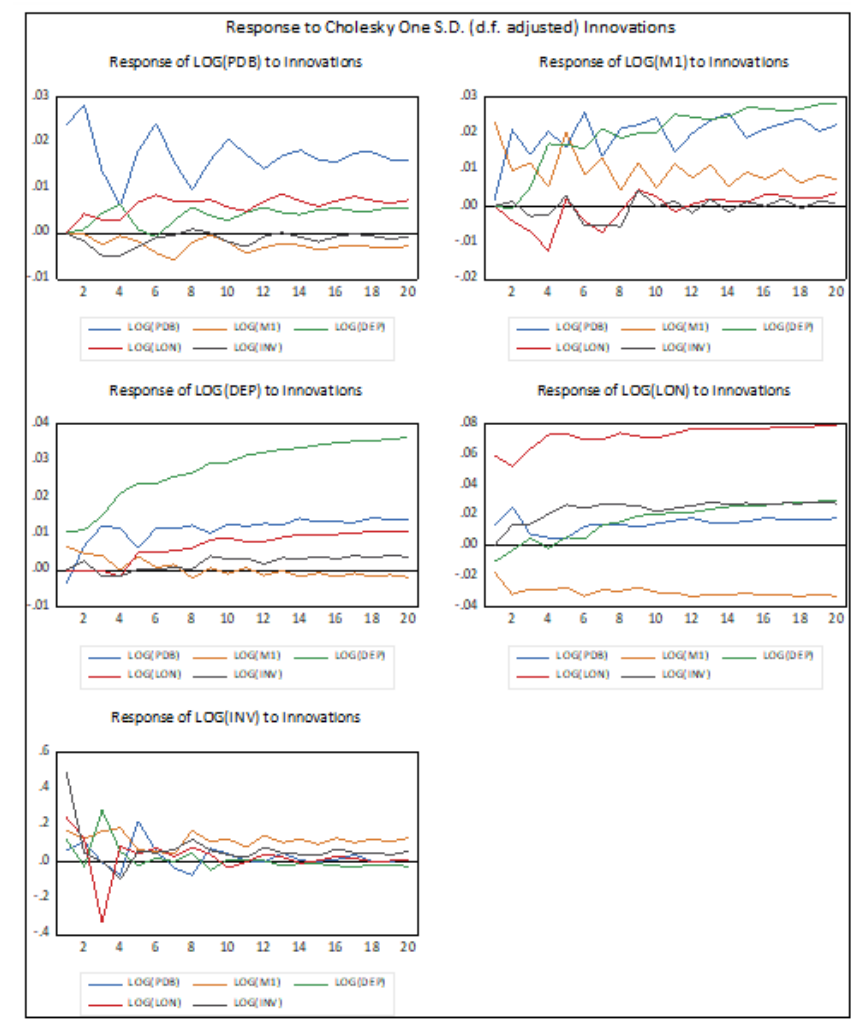

Fig. 1. Hasil Impulse Response Result of VECM Model 2010:1-2020:2

Based on the picture above, it can be seen that in the first period (quarter-1) changes in money supply logs (M1) and changes in log output (GDP) were more dominant in changes in the deposit banking system LOG (DEP), while in the long term (quarter 15-20) changes in bank credit LOG (LON) and changes in investment LOG (INV) are more dominant in changes in the deposit banking system LOG (DEP). In the first period (quarter 1) changes in money 
supply LOG (M1), changes in LOG output (GDP), and changes in bank credit are more dominant in changes in banking credit LOG (LON), while in the long term (quarter 15-20) changes in bank deposits LOG (DEP) and changes in investment LOG (INV) are more dominant in changes in banking credit LOG (LON). In the first period (quarter-1) changes in bank credit LOG (LON) have a dominant effect on changes in investment LOG (INV) but the contribution of bank credit in influencing investment changes has decreased until the 20th period, it is different from the contribution of changes in money supply which is increasingly increased starting from the first period. Random shocks on investment will result in dominant changes in money supply LOG (M1), bank loans, or credits LOG (LON) and output.

Table 6. Variance Decomposition

\begin{tabular}{|c|c|c|c|c|c|}
\hline Period & LOG(PDB) & LOG(M1) & LOG(DEP) & LOG(LON) & LOG(INV) \\
\hline \multicolumn{6}{|c|}{ Money Suppl (M1) } \\
\hline 1 & 0.450797 & 99.54920 & 0.000000 & 0.000000 & 0.000000 \\
\hline 2 & 39.95737 & 58.29425 & 0.067108 & 1.560814 & 0.120460 \\
\hline 5 & 39.09533 & 35.93057 & 17.79658 & 6.529306 & 0.648218 \\
\hline 10 & 44.96590 & 19.91859 & 29.68239 & 3.864174 & 1.568950 \\
\hline 15 & 41.97246 & 14.84610 & 39.82558 & 2.343166 & 1.012692 \\
\hline 20 & 40.68980 & 11.69769 & 45.09578 & 1.793651 & 0.723076 \\
\hline \multicolumn{6}{|l|}{ Deposit } \\
\hline 1 & 8.741301 & 25.69629 & 65.56241 & 0.000000 & 0.000000 \\
\hline 2 & 16.21406 & 17.67684 & 64.35467 & 0.000802 & 1.753627 \\
\hline 5 & 18.93693 & 4.718755 & 74.43003 & 1.322963 & 0.591327 \\
\hline 10 & 15.87941 & 1.549064 & 78.04430 & 3.985001 & 0.542229 \\
\hline 15 & 14.15515 & 0.815004 & 79.50397 & 4.903611 & 0.622264 \\
\hline 20 & 13.28423 & 0.574927 & 79.85279 & 5.585050 & 0.703002 \\
\hline \multicolumn{6}{|l|}{ Loan } \\
\hline 1 & 4.386053 & 7.161010 & 2.745133 & 85.70780 & 0.000000 \\
\hline 2 & 9.606996 & 14.97845 & 1.409776 & 71.83839 & 2.166382 \\
\hline 5 & 3.444234 & 13.54455 & 0.661586 & 76.68919 & 5.660437 \\
\hline 10 & 2.981932 & 13.09761 & 2.329530 & 73.88712 & 7.703813 \\
\hline 15 & 3.036247 & 12.69337 & 4.127576 & 72.05298 & 8.089832 \\
\hline 20 & 3.155307 & 12.43439 & 5.556771 & 70.61640 & 8.237124 \\
\hline \multicolumn{6}{|c|}{ Investment } \\
\hline 1 & 1.093614 & 8.386525 & 4.380365 & 16.62624 & 69.51325 \\
\hline 2 & 3.925564 & 11.24638 & 4.069083 & 18.80476 & 61.95421 \\
\hline 5 & 9.607207 & 14.90227 & 13.48760 & 26.66891 & 35.33402 \\
\hline 10 & 10.17817 & 19.73870 & 12.16741 & 24.59449 & 33.32123 \\
\hline 15 & 9.587453 & 24.62145 & 11.26522 & 22.79013 & 31.73575 \\
\hline 20 & 8.905545 & 29.32020 & 10.58152 & 20.91146 & 30.28127 \\
\hline \multicolumn{6}{|l|}{ Output } \\
\hline 1 & 100.0000 & 0.000000 & 0.000000 & 0.000000 & 0.000000 \\
\hline 2 & 98.39122 & 0.001417 & 0.057887 & 1.331884 & 0.217590 \\
\hline 5 & 90.04854 & 0.444666 & 2.882566 & 3.806995 & 2.817236 \\
\hline 10 & 85.47390 & 1.747958 & 3.060291 & 8.130753 & 1.587100 \\
\hline 15 & 82.81341 & 2.140241 & 4.126077 & 9.591150 & 1.329125 \\
\hline 20 & 81.03843 & 2.200357 & 4.984788 & 10.72186 & 1.054562 \\
\hline
\end{tabular}

Based on the table above, it can be seen that in the first period the shock response of banking deposits (DEP) to shocks in money stocks (M1) was positive, meaning that the contribution of changes in money supply (M1) in influencing changes in banking deposits (DEP) was 25.7 percent, but until period 20 the contribution of changes in money supply 
decreased to only 0.6 percent. In the first period, the response of bank credit shocks (LON) to bank deposit shocks (DEP) was positive, but the contribution of changes in Bank Deposit (DEP) in influencing changes in bank credit (LON) was only 2.7 percent, taking up to a period of 15-20 to strengthen the contribution. changes (DEP) to changes in bank credit (LON) to 5.5 percent. in the first period, the investment shock response (INV) to bank credit shocks (LON) was positive, meaning that the contribution of changes in bank lending (LON) in influencing investment changes (INV) was 16.6 percent and continued to increase until the third period, but over time it arrived. with a period of 20 , the contribution of changes in bank lending (LON) has decreased to only 20.9 percent, and the aggregate output (GDP) shock response to investment shocks (INV) is positive, while the contribution of changes in investment (INV) to changes in output (GDP) has just occurred in the second period, which is 0.2 percent, there was an increase in the investment contribution in periods four and five, but it decreased until period 20 to only 1 percent.

Based on the description above, it can be seen that the monetary policy instrument used to influence output through the bank lending channel is still weak, this can be seen in the response to the shock of monetary policy instruments received on each variable is not sustainable. There is a gap in the response of the bank loan variable to the bank deposit shock and the investment surprise response to the bank loan shock. So it takes a long time for the expansion of monetary policy instruments to investment that has an impact on output. This finding is in line with the results of research (Khaliq, 2013; Mentari N et al., 2018; Abuka et al., 2019) which states that the role of bank loans in supporting the development of the real sector has not been achieved optimally and the effectiveness of credit channels is weaker than inflation. expectation channel in Indonesia. This is due to several things, firstly there is global uncertainty that affects domestic conditions, namely from the demand side, reduced demand for credit by corporations, from the supply side, caution from the banking sector in selecting new credit applications by the public which causes credit to be held back. . Besides, there is access to foreign loans owned by banks and large companies as an alternative source of credit financing and investment financing (Pohan, 2008).

\section{Conclusions}

Research on monetary policy using bank lending channels uses the latest data, namely the period 2010:1 - 2020: 2. We revisit the question of how the mechanism of monetary policy transmission through bank lending channels in Indonesia. The results of the VECM analysis show that the Monetary Policy transmission mechanism through the bank lending channel still has a weak influence on the output, Therefore, from the demand side, it is necessary to seek new market shares for export purposes in addition to maintaining existing ones to restore domestic corporate credit demand, and from the supply side, banks must provide easy access for MSMEs to obtain loans while still prioritizing the principle of prudence.

\section{References}

[1] Aban, M. J. A. C. (2013). Transmission of Monetary Policy through the Bank Lending Channel in the Philippines. International Journal of Trade, Economics, and Finance, 4(1), 37-42. https://doi.org/10.7763/ijtef.2013.v4.257

[2] Abuka, C., Alinda, R. K., Minoiu, C., Peydró, J. L., \& Presbitero, A. F. (2019). 
Monetary policy and bank lending in developing countries: Loan applications, rates, and real effects. Journal of Development Economics, 139(March), 185-202. https://doi.org/10.1016/j.jdeveco.2019.03.004

[3] Anwar, S., and Phi, L. (2018). Channels of monetary policy transmission in Vietnam. $\begin{array}{llll}\text { Journal of Policy } & \text { Modeling, } & \text { 409-729. }\end{array}$ https://doi.org/10.1016/j.jpolmod.2018.02.004

[4] Bernanke, B., \& Blinder, A. (1988). Money, credit, and aggregate demand. Am. Econ. Rev., 82, 901-921. https://doi.org/10.1016/S0197-2510(11)70055-9

[5] Bernanke, B., \& Blinder, A. (1992). The Federal Funds Rate and The Channels of Monetary Transmission. Am. Econ. Rev., 901-921.

[6] Firdaus, M. (2020). Aplikasi Ekonometrika Dengan e-views, Stata, Dan R (Cetakan 1). Bogor-Indonesia: IPB Press.

[7] Goeltom, M., S. (2005). The transmission mechanisms of monetary policy in Indonesia. Bank for International Settlements (BIS), (35), 309-332.

[8] Kashyap, A. K., \& Stein, J. C. (2000). What Do a Million Observations on Banks Say about the Transmission of Monetary Policy? American Economic Review, 90(3), 407 428 .

[9] Khaliq, A. (2013). Dampak kredit perbankan terhadap sektor riil dan finansial: model. Finance and Banking Journal, 15(1), 1-21.

[10] Mahathanaseth, I., \& Tauer, L. . (2019). Monetary Policy Transmission Through The Bank Lending Channel In Thailand. Journal of Asian Economics, 60, 14-32. https://doi.org/10.1016/j.asieco.2018.10.004

[11] Mentari N, R., Hayati, B., \& A G, E. (2018). Effectiveness of monetary policy transmission in Indonesia. JEJAK: Jurnal Ekonomi Dan Kebijakan, 11(1), 189-206. https://doi.org/https://doi.org/10.15294/jejak. v11i1.12385

[12] Mishkin, F. S. (2004). The Economics of Money, Banking, and Financial Markets (Seventh Ed). Ne: Addison Wesley.

[13] Sun, S., Gan, C., \& Hu, B. (2010). Bank lending channel in China's monetary policy transmission mechanism: A VECM approach. Investment Management and Financial Innovations, 7(2), 177-188.

[14] Tanjung A. A., Afifuddin, S., Daulay, M., and Ruslan, D. (2017). Relationship Between Monetary Policy, Fiscal, Country Risk, and Macroeconomic Variable in Indonesia. International Journal of Economic Research, 14(15), 207-220.

[15] Tanjung, A. A., Daulay, M., Irsad, I., \& Ruslan, D. (2019). The impact of monetary and fiscal policy on poverty in Indonesia. Journal of Applied Economic Sciences, XIV(4(66)), 1068-1073. https://doi.org/10.14505/jaes.v14.4(66).12

[16] Utari, G. . D., Arimurti, T., \& Kurniati, I. N. (2012). Optimal Credit Growth. Bulletin of Monetary Economics and Banking, Bank Indonesia, 15(2), 1-32.

[17] Verbeek, M. (2004). A Guide To Modern Econometrics (2nd ed.). England: Jhon Wiley \& Sons, Ltd.

[18] Yarasevika, S., Tongato, A., \& Muthia, A. C. (2015). Bank Lending Channel in Indonesia's Monetary Policy Transmission Mechanism: A VECM approach. Proceedings of ISER 5th International Conference, Singapore, (September), 27-32. 